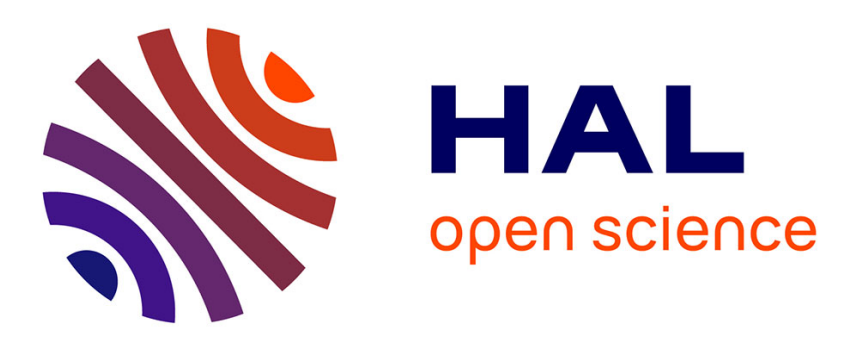

\title{
First record of (Nematode: Metastrongyloidea) in a pine marten from Ireland
}

\author{
Peter Stuart, Conall J. Hawkins, D. P. Sleeman, Colin Lawton
}

\section{To cite this version:}

Peter Stuart, Conall J. Hawkins, D. P. Sleeman, Colin Lawton. First record of (Nematode: Metastrongyloidea) in a pine marten from Ireland. European Journal of Wildlife Research, 2010, 56 (4), pp.679-680. 10.1007/s10344-010-0376-y . hal-00581872

\section{HAL Id: hal-00581872 \\ https://hal.science/hal-00581872}

Submitted on 1 Apr 2011

HAL is a multi-disciplinary open access archive for the deposit and dissemination of scientific research documents, whether they are published or not. The documents may come from teaching and research institutions in France or abroad, or from public or private research centers.
L'archive ouverte pluridisciplinaire HAL, est destinée au dépôt et à la diffusion de documents scientifiques de niveau recherche, publiés ou non, émanant des établissements d'enseignement et de recherche français ou étrangers, des laboratoires publics ou privés. 


\title{
First record of Skrjabingylus petrowi (Nematode: Metastrongyloidea) in a pine marten Martes martes from Ireland
}

\author{
Peter Stuart • Conall J. Hawkins • D. P. Sleeman • \\ Colin Lawton
}

Received: 18 November 2009/Revised: 25 February 2010/Accepted: 5 March 2010/Published online: 1 April 2010

(C) Springer-Verlag 2010

\begin{abstract}
We report the first record of the parasitic nematode Skrjabingylus petrowi in Ireland, the fifth record of $S$. petrowi outside Russia. Twenty-three of the nematodes were removed from the skull of a male road kill pine marten Martes martes from Co. Tipperary. The spicule lengths measured in the male nematodes removed ranged from 410 to $500 \mu \mathrm{m}$, which is in agreement with the range of 410 to $605 \mu \mathrm{m}$ previously recorded for $S$. petrowi. This investigation presents further evidence that anatomical measurements are required for the accurate diagnosis of Skrjabingylus spp. and that $S$. petrowi has a host preference for Martes spp.
\end{abstract}

Keywords Skrjabingylus petrowi Martes martes .

Nematoda $\cdot$ Parasite $\cdot$ Ireland

Members of the family Mustelidae are the definitive hosts of the Metastrongyloid nematode of the genus Skrjabingylus Petrov, 1927. Skrjabingylus spp. are found within the frontal sinuses of their definitive hosts, and infection can result in abscesses, perforations and other damage to the skull (Hansson 1968). Following Heddergott's (2009) first record of the nematode Skrjabingylus petrowi in pine

Communicated by C. Gortázar

P. Stuart $(\bowtie) \cdot$ C. J. Hawkins $\cdot$ C. Lawton

Mammal Ecology Group, School of Natural Sciences,

National University of Ireland,

Galway, Ireland

e-mail: P.Stuart1@nuigalway.ie

D. P. Sleeman

Department of Zoology, Ecology and Plant Science,

University College Cork,

Cork, Ireland martens Martes martes from Germany, we identified $S$. petrowi in a pine marten from Ireland. Due to new legal protection of the pine marten in Ireland, its population is thought to be increasing and expanding into new areas (Marnell et al. 2009). This is the first record of S. petrowi in Ireland and makes it the fifth record of $S$. petrowi outside Russia, where it was first described (Heddergott 2009). Prior to this, the only Skrjabingylus spp. reported from Ireland have been Skrjabingylus nasicola which was only found in the Irish stoat Mustela erminea hibernica (Sleeman 1988). The skull we investigated was taken from a male (first-year age class by cementum analysis) road kill pine marten found in Roscrea, Co. Tipperary $\left(52^{\circ} 57^{\prime} 0^{\prime \prime} \mathrm{N}\right.$, $\left.7^{\circ} 49^{\prime} 0^{\prime \prime} \mathrm{W}\right)$. It has previously been reported that $90 \%$ of Russian pine martens from the first-year age class were infected with Skrjabingylus spp., decreasing to $50 \%$ once they passed 3 years of age (King 1977). No perforations were observed in the skull. The skull was frozen, cut sagittally and immersed in a $0.7 \%$ saline solution so that nematodes could be extracted under a dissection microscope following the methods of Hansson (1968). All nematodes were examined with a light microscope to take morphological measurements and to determine sex. Twenty-three nematodes were removed, 13 from the right sinus frontalis (five males, eight females) and ten from the left sinus frontalis (five males, five females). The anatomical measurements taken were in agreement with those previously taken for $S$. petrowi (Table 1). One of the diagnostic features that distinguish Skrjabingylus spp. from each other is spicule length (Fig. 1). S. petrowi spicules have been previously recorded with lengths of 410 to $605 \mu \mathrm{m}$ (Heddergott 2009). Spicule lengths measured in the specimens from the present study ranged from 410 to $500 \mu \mathrm{m}$ (Table 1). This also puts the spicules measured 
Table 1 Range of values of selected morphological measurements of $S$. petrowi (table amended from Heddergott (2009) to include results from present study)

\begin{tabular}{|c|c|c|c|c|c|}
\hline $\begin{array}{l}\text { Skrjabingylus } \\
\text { petrowi }\end{array}$ & $\begin{array}{l}\text { Measurements/ } \\
\text { characteristics }\end{array}$ & $\begin{array}{l}\text { Kontrimavichus et al. } \\
\text { (1985) }\end{array}$ & $\begin{array}{l}\text { Koubek et al. } \\
(2004)\end{array}$ & $\begin{array}{l}\text { Heddergott } \\
(2009)\end{array}$ & $\begin{array}{l}\text { Present } \\
\text { study }^{\mathrm{a}}\end{array}$ \\
\hline \multirow[t]{3}{*}{ Males } & Body length (mm) & $11.0-15.6$ & $12.4-14.7$ & $11.7-14.9$ & $11.6-14.48$ \\
\hline & Body width (mm) & - & $0.47-0.53$ & $0.50-0.56$ & $0.45-0.60$ \\
\hline & Spicule length $(\mu \mathrm{m})$ & $449-570$ & $506-540$ & $512-563$ & $410-500$ \\
\hline \multirow[t]{2}{*}{ Females } & Body length (mm) & $28.0-39.5$ & $27.4-31.5$ & $29.5-33.8$ & $24.1-33.1$ \\
\hline & Body width (mm) & - & $0.87-0.99$ & $0.79-0.91$ & $0.73-1.0$ \\
\hline
\end{tabular}

${ }^{\text {a }}$ Male nematodes, $n=8$; female nematodes, $n=10$

outside the 150 to $324 \mu \mathrm{m}$ range of measurements previously recorded for S. nasicola (Heddergott 2009), the Skrjabingylus species previously recorded in Ireland. It is possible that $S$. petrowi was recently introduced to Ireland carried by an introduced host species. However, it is more plausible that it went undetected in Ireland until now. Apart from Sleeman's (1988) examination of two pine martens, we are not aware of any other investigation into the presence of Skrjabingylus spp. in pine martens in Ireland. The need for anatomical measurements of the nematodes to identify Skrjabingylus spp. to the species level is in agreement with Heddergott's (2009) statement that cleaned skulls are not suitable for accurate diagnosis of infections of

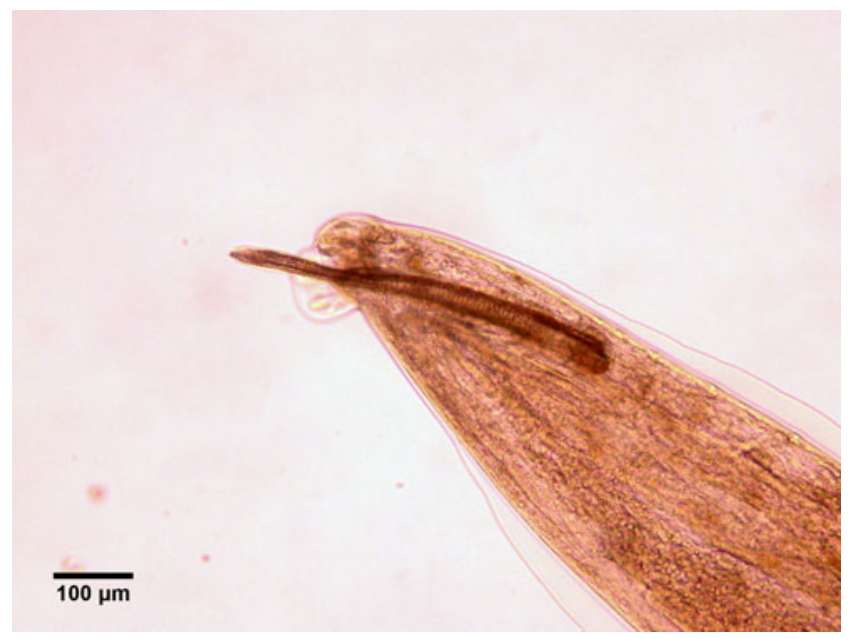

Fig. 1 Spicule (length $500 \mu \mathrm{m}$ ) of a male S. petrowi (Nematoda: Metastrongyloidea) that was removed from the right sinus frontalis of a pine marten (M. martes)
Skrjabingylus spp. This investigation also presents further evidence of Heddergott's (2009) assumption that S. petrowi has a host preference for Martes spp. and that earlier records of $S$. nasicola in Martes spp. may have been erroneous.

Acknowledgements Thanks to Simon White who donated the pine marten. We are grateful to Mike Heddergott for confirming the nematode as Skrjabingylus petrowi. Thanks to Albert Lawless for help in preparing the photo and advice on microscopy. Thanks also to Heikki Henttonen for advice on preserving the nematodes. Peter Stuart is funded under the Research Stimulus Fund Programme by the Irish Department of Agriculture and Food. Conall Hawkins is sponsored by IRCSET, through the Embark Initiative. Thanks to two anonymous reviewers for comments on the manuscript.

\section{References}

Hansson I (1968) Cranial Helminth parasites in species of Mustelidae: I. Frequency and damage in fresh Mustelids from Sweden. Oikos 19:217-233

Heddergott M (2009) First record of Skrjabingylus petrowi (Nematoda: Metastrongyloidea) in a pine marten (Martes martes) in Germany. Eur J Wildl Res 55:543-546

King CM (1977) The effects of the nematode parasite Skrjabingylus nasicola on British weasels (Mustela nivalis). J Zool 182:225-249

Kontrimavichus VL, Delyamure SL, Boev SN (1985) Metastrongyloids of domestic and wild animals, vol 26, Fundamentals of nematology. Oxonian, New Delhi, p 298

Koubek P, Baruš V et al (2004) Presence of Skrjabingylus petrowi (Nematoda) in central Europe. Parasitol Res 94:301-303

Marnell F, Kingston N, Looney D (2009) Ireland red list no. 3: terrestrial mammals, national parks and wildlife service. Department of the Environment, Heritage and Local Government, Dublin

Sleeman DP (1988) Skrjabingylus nasicola (Leuckhart) (Metastrongyloidea) as a parasite of the Irish stoat. Ir Nat J 22:525-527 